\title{
Nanofiltration-Concept and Prospects
}

\author{
Nida tabassum khan ${ }^{1}$ \\ Department of Biotechnology, Faculty of Life Sciences \& Informatics, Balochistan University of Information Technology, Balochistan.
}

Corresponding Author: Nida tabassum khan Department of Biotechnology, Faculty of Life Sciences \& Informatics, Balochistan.

Received Date: September 06, 2021; Accepted Date: September 11, 2021; Published Date: October 15, 2021

Citation: Nida T khan (2021) Nanofiltration-Concept and Prospects J Pharmaceutics and Pharmacology Research. 4(4); DOI: 10.31579/2693$7247 / 047$

Copyright: () Nida tabassum khan, This is an open access article distributed under the Creative Commons Attribution License, which permits unrestricted use, distribution, and reproduction in any medium, provided the original work is properly cited.

\begin{abstract}
Nanofiltration is a pressure-driven film measure for fluid stage detachments. It is employed in numerous applications due to lower energy utilization and higher motion rates. The properties of nanofiltration membranes lie between those of non-permeable reverse osmosis layers and permeable ultrafiltration layers where partition is typically thought to be because of size rejection and, sometimes, charge impacts. The improvement of nanofiltration development as a practical association over continuous years has provoked a pivotal extension in its application in different endeavours, for instance, treatment of blurring effluents from the material industries, division of medications from development stocks, demineralization in the dairy business, and metal recovery from wastewater and disease clearing
\end{abstract}

Key Words: reverse osmosis; ultrafiltration; surfactants; electrodialysis; innovation; non-permeable

\section{Introduction}

Nanofiltration (NF) is a pressure driven membrane process based on the separation capabilities of reverse osmosis and ultrafiltration [1]. Nanofiltration is often used where the divalent ions ( $\mathrm{Ca}, \mathrm{Mg}$ etc) have to be removed but it can also be employed in the separation of ions from solutes such as small molecules of sugars [2,3]. The molecular weight cut off of nanofiltration membranes is between 200 - 1000 Daltons, which means pore size ranges between $1-10 \mathrm{~nm}$ [4]. Typical rejections of NF membranes are $60 \%$ for $\mathrm{NaCl}, 98 \%$ for magnesium sulphate, glucose and sucrose $[5,6]$. Generally, this opens up the possibilities enhancing process efficiency and the production of new products, particularly in the food industry and biotechnology [7]. Some other specific applications of nanofiltration are the removal of colour, removal of trihalomethane precursors from surface water, removal of low molecular weight species such as organics in pharmaceutical production, surfactants from waste waters etc $[8,9]$. The potential applications of nanofiltration are in food industry and environmental protection [10].

\section{Nanofiltration membrane process}

Reverse osmosis membranes are basically non-permeable, and allows passage of fluid by high working pressing factor of 20 to 100 bars [11]. Nanofiltration membranes has pore size of 1-5 $\mathrm{nm}$ and it can hold particles, and low sub-atomic weight organics [12]. It has essentially higher water porousness than reverse osmosis membranes and works at lower pressure normally 7 to 30 bar [13]. Similarly, ultrafiltration membranes possess pore size ranges from 5 to $20 \mathrm{~nm}$ and holds fine colloids, macromolecules, and microorganism and works with pressure scope of 1 to 10 bar [14]. The other types of membranes that are utilized in fluid measures are microfiltration (MF), electrodialysis (ED), fluid film (LM), pervaporation (PV), fume penetration (VP), and gas saturation (GP) $[15,16,17]$.

\section{Nanofiltration membrane construct}

Nanofiltration membranes possess a fixed charge created by the separation of surface assemblies such as sulphonated or carboxyl acids [18]. The characteristics of nanofiltration membranes, subsequently, permits particles to be separated by a mix of the size and ultrafiltration electrical impacts and the particle collaboration systems of reverse osmosis [19]. Such types of membrane presented novel technique in wastewater treatment [20]. The pore size of nanofiltration membrane is approximately $1 \mathrm{~nm}$ which allows even little uncharged solutes to be dismissed while the surface electrostatic properties permit monovalent particles to be sensibly very much communicated with multivalent particles for the most part held [21,22]. These features make this membrane very valuable in the fractional process and in solutes expulsion from complex interaction streams [23]. Nanofiltration membranes are one of the promising advances for the treatment of typical normal matter and inorganic defilements in surface water since surface water has low osmotic squeezing factor therefore a low-pressure movement of 
nanofiltration is possible [24]. In the nanofiltration of surface waters, ordinary normal combinations, which have commonly enormous iotas appeared differently in relation to film pore size, could be dispensed with by sieving instrument, however the inorganic salts by the charge effect of the layers and particles [25,26].

\section{Separation mechanisms in nanofiltration}

Nanofiltration take advantage of lower working pressure factor appeared differently in relation to reverse osmosis, and higher regular excusal diverged from ultrafiltration [27]. For the colloids and immense particles, physical sieving would be the prevalent excusal framework however for the particles and lower sub-nuclear weight substances, plan spread instrument and charge effect of membrane plays an important role in segmentation [28]. There are four stages of nanofiltration separation which are as follows:

1. Wetted surface: Water binds with the membrane through hydrogen bonding and the atoms which structure the hydrogen holding with the layer can be moved [29].

2. Preferential sorption/Capillary dismissal: Membrane for nanofiltration is assorted and microporous, and static revulsion occurs because of numerous electrostatic factors [30].

3. Solution dissemination: Solutes and solubles break up in the membrane due to dispersion [31].

4. Charged slim: Electric twofold layer in the pores allows release of particles of similar charges and counter-particles are dismissed because of the streaming potential [32]. The excusal of uncharged molecules is overpowered by size preclusion, while that of ionic species is influenced by both size dismissal and electrostatic joint efforts [33]. Electrostatic ascribes of nanofiltration membranes have been known to play an important part in excusal anions, to be explicit, negative zeta potential on the layer surface changes with different $\mathrm{pH}$ and gathering of electrolytes [34].

\section{Membrane fouling in the nanofiltration process}

Like some other film measures, nanofiltration membranes are vulnerable to layer fouling [35]. Layer fouling is one of the enormous hardships in any film or membrane layouts therefore understanding the fouling instrument and perceiving a suitable control decision is one of the crucial sections of this applications [36]. The responses for fouling issues require a multipronged approach including the film properties, useful conditions, feed characteristics, etc [37]. The nanofiltration membrane fouling could be a direct result of inorganic precipitation or scaling, colloidal fouling, regular adsorption and moreover biofouling [38]. While biofouling is huge in long stretch, without a doubt, biofouling happens exclusively after normal or inorganic or colloidal fouling [39]. Since coordinated efforts among solutes and the membrane layers are deficiently seen, it is possible that effects like charge associations, crossing, and hydrophobic affiliations may accept a huge part in membrane fouling [40]. Membrane layers with greater pores show a more essential decline as filtration proceeds because of inward plugging up [41]. In any case, movement decline isn't actually due to fouling but various factors like center polarization or osmotic factor component or film compaction can appear as fouling during the nanofiltration association [42]. Concerns like contemplated three limits, silt thickness record (SDI), modified fouling document (MFI), and the immediate association of the mass trade coefficient (MTC) to investigate the fouling [43]. Regardless, no association between's these limits were procured exhibiting that the fundamental filtration laws most likely will not be considerable for nanofiltration measures [44]. It was reported that the regular blends with sub-nuclear weight higher than $30 \mathrm{kDa}$ was responsible for membrane fouling [45]. In addition, change in fouling framework after $20 \mathrm{~h}$ movement, possibly on account of the associations of the hydrophobic and hydrophilic pieces of organics [46]. In another study it was reported that the use of especially hydrophilic films with pore size of $1-2 \mathrm{~nm}$ and low working strain could reduce fouling because hydrophilic membranes were more resistant to fouling regardless of pore size [47]. Membrane fouling would be amazingly genuine in charged layers which can attract the oppositely charged organics with no issue however in case of particles like calcium, phosphorus, aluminium and iron, etc film fouling during water treatment measure were further developed [48].

On the other hand, colloidal materials could cause more fouling than natural materials in nanofiltration because of the following reasons:

- Natural fouling due to the presence of organic species on the membrane surface [49]

- Deficiency of saturate transition through the membrane [50]

- Due to the testimony of natural substances [51]

- $\quad$ Scaling which is characterized as the arrangement of mineral stores accelerating from the feed stream to the film surface [52].

\section{Control of membrane fouling}

Membrane fouling is ordinarily controlled either by working the system inside the essential movement range or adding engineered materials or conceivably by pre-treatment which is the most uplifting answer for fouling control [53]. Normally used channel media is not sufficient to reduce the fouling, therefore a combination of coagulation, ozonation and biofiltration is utilized as a better option [54]. Extension of a polyelectrolyte overhauled the molecule excusal in nanofiltration [55]. Incited carbon adsorption is an outstandingly convincing pretreatment measure Since the basic decrease in fouling is predominantly a result of speedy, irreversible adsorption of regular substances on the film surface, giving a pre-treatment, for instance, adsorption or flocculation of organics before passing the feed course of action through the layer is extraordinarily amazing response for the film fouling issue [56,57]. Pretreatment of the feed to nanofiltration is one of the huge considerations to guarantee lower membrane fouling [58]. High molecular weight solids can damage the film surface unequivocally and break the stream in the filtration structure [59]. Recently, high-rate flocculation and appealing molecule exchange sap have been endeavoured to kill hydrophobic and hydrophilic organics exclusively to diminish the regular fouling on the nanofilter layers [60].

\section{Conclusion}

Since nanofiltration shows properties between those of ultrafiltration and reverse osmosis, both charge and size of atom accept huge part in nanofiter excusal part. Thus, nanofiltration membrane is defined as a charged ultrafiltration structure with a low infolding reverse osmosis system.

\section{References}

1. Mohammad, A. W, Teow, Y. H, Ang, W. L, Chung, Y. T, OatleyRadcliffe, et al (2015). Nanofiltration membranes review: Recent advances and future prospects. Desalination, 356, 226-254.

2. Petersen, R. J. (1993). Composite reverse osmosis and nanofiltration membranes. Journal of membrane science, 83(1), 81-150.

3. Raman, L. P, Cheryna, M., \& Rajagopalan, N. (1994). Consider nanofiltration for membrane separations. Chemical Engineering Progress;(United States), 90(3).

4. Schäfer, A., Fane, A. G., \& Waite, T. D. (Eds.). (2005). Nanofiltration: principles and applications. Elsevier.

5. Bowen, W. R., \& Mohammad, A. W. (1998). Characterization and prediction of nanofiltration membrane performance a general assessment. Chemical Engineering Research and Design, 76(8), 885-893. 
6. Eriksson, P. (1988). Nanofiltration extends the range of membrane filtration. Environmental Progress, 7(1), 58-62.

7. Volkov, A. V., Korneeva, G. A., \& Tereshchenko, G. F. (2008). Organic solvent nanofiltration: prospects and application. Russian Chemical Reviews, 77(11), 983.

8. Peeters, J. M. M, Boom, J. P, Mulder, M. H. V, \& Strathmann, H. (1998). Retention measurements of nanofiltration membranes with electrolyte solutions. Journal of membrane science, 145(2), 199-209.

9. Oatley-Radcliffe, D. L, Walters, M, Ainscough, T. J, Williams, P. M, Mohammad, A. W., \& Hilal, N. (2017). Nanofiltration membranes and processes: A review of research trends over the past decade. Journal of Water Process Engineering, 19, 164-171.

10. Abdel-Fatah, M. A. (2018). Nanofiltration systems and applications in wastewater treatment. Ain Shams Engineering Journal, 9(4), 3077-3092.

11. Bowen, W. R., \& Mohammad, A. W. (1998). Characterization and prediction of nanofiltration membrane performance-a general assessment. Chemical Engineering Research and Design, 76(8), 885-893.

12. Tul Muntha, S., Kausar, A., \& Siddiq, M. (2017). Advances in polymeric nanofiltration membrane: A review. Polymer-Plastics Technology and Engineering, 56(8), 841-856.

13. Chun-Te Lin, J., \& Livingston, A. G. (2007). Nanofiltration membrane cascade for continuous solvent exchange. Chemical Engineering Science, 62(10), 2728-2736.

14. Marchetti, P., Peeva, L., \& Livingston, A. (2017). The selectivity challenge in organic solvent nanofiltration: membrane and process solutions. Annual review of chemical and biomolecular engineering, 8, 473-497.

15. Bowen, W. R., \& Welfoot, J. S. (2002). Predictive modelling of nanofiltration: membrane specification and process optimisation. Desalination, 147(1-3), 197-203.

16. Xu, Y., \& Lebrun, R. E. (1999). Investigation of the solute separation by charged nanofiltration membrane: effect of $\mathrm{pH}$, ionic strength and solute type. Journal of membrane science, 158(1-2), 93-104.

17. Ji, Y., An, Q., Zhao, Q., Chen, H., Qian, J., \& Gao, C. (2010). Fabrication and performance of a new type of charged nanofiltration membrane based on polyelectrolyte complex. Journal of Membrane Science, 357(1-2), 80-89.

18. Gu, Y. H., Yan, X., Chen, Y., Guo, X. J., \& Lang, W. Z. (2020). Layer-by-layer assembled GO-based membranes with high longstanding stability and chemical resistance applied in dye separation and desalination. 2D Materials, 7(4), 045016.

19. Xu, G. R., Liu, X. Y., Xu, J. M., Li, L., Su, H. C., Zhao, H. L., \& Feng, H. J. (2018). High flux nanofiltration membranes based on layer-by-layer assembly modified electrospun nanofibrous substrate. Applied Surface Science, 434, 573-581.

20. Wang, T., Qiblawey, H., Sivaniah, E., \& Mohammadian, A. (2016). Novel methodology for facile fabrication of nanofiltration membranes based on nucleophilic nature of polydopamine. Journal of Membrane Science, 511, 65-75.

21. García-Martín, N., Silva, V., Carmona, F. J., Palacio, L., Hernández, A., \& Prádanos, P. (2014). Pore size analysis from retention of neutral solutes through nanofiltration membranes. The contribution of concentration-polarization. Desalination, $344,1-11$.

22. Bowen, W. R., \& Welfoot, J. S. (2002). Modelling the performance of membrane nanofiltration - critical assessment and model development. Chemical engineering science, 57(7), 11211137.

23. Dischinger, S. M., McGrath, M. J., Bourland, K. R., Noble, R. D., \& Gin, D. L. (2017). Effect of post-polymerization anion- exchange on the rejection of uncharged aqueous solutes in nanoporous, ionic, lyotropic liquid crystal polymer membranes. Journal of Membrane Science, 529, 72-79.

24. Liu, X., \& Bruening, M. L. (2004). Size-selective transport of uncharged solutes through multilayer polyelectrolyte membranes. Chemistry of materials, 16(2), 351-357.

25. Werber, J. R., Osuji, C. O., \& Elimelech, M. (2016). Materials for next-generation desalination and water purification membranes. Nature Reviews Materials, 1(5), 1-15.

26. Schaep, J., Van der Bruggen, B., Vandecasteele, C., \& Wilms, D. (1998). Influence of ion size and charge in nanofiltration. Separation and Purification Technology, 14(1-3), 155-162.

27. Košutić, K., Novak, I., Sipos, L., \& Kunst, B. (2004). Removal of sulfates and other inorganics from potable water by nanofiltration membranes of characterized porosity. Separation and Purification Technology, 37(3), 177-185.

28. Nghiem, L. D., Schäfer, A. I., \& Elimelech, M. (2005). Pharmaceutical retention mechanisms by nanofiltration membranes. Environmental science \& technology, 39(19), 76987705 .

29. Gao, Z. F., Feng, Y., Ma, D., \& Chung, T. S. (2019). Vapor-phase crosslinked mixed matrix membranes with UiO-66-NH2 for organic solvent nanofiltration. Journal of Membrane Science, 574, 124-135.

30. Robinson, J. P., Tarleton, E. S., Millington, C. R., \& Nijmeijer, A. (2004). Solvent flux through dense polymeric nanofiltration membranes. Journal of membrane science, 230(1-2), 29-37.

31. Nguyen, N. N., Fargues, C., Lewandowski, R., Guiga, W., \& Lameloise, M. L. (2012, September). Assessing nanofiltration and reverse osmosis for the detoxification of fermentable solutions. In Euromembrane Conference 2012 (Vol. 44, p. np). Academic Press-Elsevier.

32. Park, A. H. A., Zhu, C., Fan, L. S., \& Sandvik, P. (2000). Particle Technology. Kirk-Othmer Encyclopedia of Chemical Technology, 1-51.

33. Braghetta, A. H. (1995). The influence of solution chemistry and operating conditions on nanofiltration of charged and uncharged organic macromolecules (Doctoral dissertation, The University of North Carolina at Chapel Hill).

34. Cheng, S., Oatley, D. L., Williams, P. M., \& Wright, C. J. (2011). Positively charged nanofiltration membranes: review of current fabrication methods and introduction of a novel approach. Advances in Colloid and Interface Science, 164(1-2), 12-20.

35. Bellona, C., Marts, M., \& Drewes, J. E. (2010). The effect of organic membrane fouling on the properties and rejection characteristics of nanofiltration membranes. Separation and Purification Technology, 74(1), 44-54.

36. Guo, W., Ngo, H. H., \& Li, J. (2012). A mini-review on membrane fouling. Bioresource technology, 122, 27-34.

37. She, Q., Wang, R., Fane, A. G., \& Tang, C. Y. (2016). Membrane fouling in osmotically driven membrane processes: A review. Journal of Membrane Science, 499, 201-233.

38. Mohammadi, T., Madaeni, S. S., \& Moghadam, M. K. (2003). Investigation of membrane fouling. Desalination, 153(1-3), 155160.

39. Vrouwenvelder, J. S., Van Paassen, J. A. M., Wessels, L. P., Van Dam, A. F., \& Bakker, S. M. (2006). The membrane fouling simulator: a practical tool for fouling prediction and control. Journal of Membrane Science, 281(1-2), 316-324.

40. Ma, H., Bowman, C. N., \& Davis, R. H. (2000). Membrane fouling reduction by backpulsing and surface modification. Journal of Membrane Science, 173(2), 191-200. 
41. Kimura, K., Hane, Y., Watanabe, Y., Amy, G., \& Ohkuma, N. (2004). Irreversible membrane fouling during ultrafiltration of surface water. Water research, 38(14-15), 3431-3441.

42. Jonsson, G., \& Prado-Rubio, O. (2011). Modeling and operation of dynamic membrane processes. In Key note at ICOM conference (Vol. 425).

43. Li, C., Sun, W., Lu, Z., Ao, X., \& Li, S. (2020). Ceramic nanocomposite membranes and membrane fouling: A review. Water research, 175, 115674.

44. Mohammad, A. W., Ng, C. Y., Lim, Y. P., \& Ng, G. H. (2012). Ultrafiltration in food processing industry: review on application, membrane fouling, and fouling control. Food and bioprocess technology, 5(4), 1143-1156.

45. Hashino, M., Hirami, K., Ishigami, T., Ohmukai, Y., Maruyama, T., Kubota, N., \& Matsuyama, H. (2011). Effect of kinds of membrane materials on membrane fouling with BSA. Journal of Membrane Science, 384(1-2), 157-165.

46. Laine, J. M., Campos, C., Baudin, I., \& Janex, M. L. (2003). Understanding membrane fouling: a review of over a decade of research. Water Science and Technology: Water Supply, 3(5-6), $155-164$.

47. Jiang, S., Li, Y., \& Ladewig, B. P. (2017). A review of reverse osmosis membrane fouling and control strategies. Science of the Total Environment, 595, 567-583.

48. Seidel, A., \& Elimelech, M. (2002). Coupling between chemical and physical interactions in natural organic matter (NOM) fouling of nanofiltration membranes: implications for fouling control. Journal of membrane science, 203(1-2), 245-255.

49. Schäfer, A. I., Fane, A. G., \& Waite, T. D. (2000). Fouling effects on rejection in the membrane filtration of natural waters. Desalination, 131(1-3), 215-224.
50. Hong, S., \& Elimelech, M. (1997). Chemical and physical aspects of natural organic matter (NOM) fouling of nanofiltration membranes. Journal of membrane science, 132(2), 159-181.

51. Fan, L., Harris, J. L., Roddick, F. A., \& Booker, N. A. (2001). Influence of the characteristics of natural organic matter on the fouling of microfiltration membranes. Water Research, 35(18), 4455-4463.

52. Iorhemen, O. T., Hamza, R. A., \& Tay, J. H. (2017). Membrane fouling control in membrane bioreactors (MBRs) using granular materials. Bioresource technology, 240, 9-24.

53. Bagheri, M., Akbari, A., \& Mirbagheri, S. A. (2019). Advanced control of membrane fouling in filtration systems using artificial intelligence and machine learning techniques: A critical review. Process Safety and Environmental Protection, 123, 229-252.

54. Kimura, K., \& Oki, Y. (2017). Efficient control of membrane fouling in MF by removal of biopolymers: Comparison of various pretreatments. Water research, 115, 172-179.

55. Mishima, I., \& Nakajima, J. (2009). Control of membrane fouling in membrane bioreactor process by coagulant addition. Water science and technology, 59(7), 1255-1262.

56. Zhang, X., Guo, J., Wang, L., Hu, J., \& Zhu, J. (2013). In situ ozonation to control ceramic membrane fouling in drinking water treatment. Desalination, 328, 1-7.

57. Yu, W., Campos, L. C., \& Graham, N. (2016). Application of pulsed UV-irradiation and pre-coagulation to control ultrafiltration membrane fouling in the treatment of micropolluted surface water. Water research, 107, 83-92.

58. Du, X., Shi, Y., Jegatheesan, V., \& Haq, I. U. (2020). A review on the mechanism, impacts and control methods of membrane fouling in MBR system. Membranes, 10(2), 24.

59. Fane, A. G., Beatson, P., \& Li, H. (2000). Membrane fouling and its control in environmental applications. Water science and technology, 41(10-11), 303-308.
This work is licensed under Creative Commons Attribution 4.0 License
To Submit Your Article Click Here: Submit Manuscript

DOI: $10.31579 / 2693-7247 / 047$
Ready to submit your research? Choose Auctores and benefit from:

$>$ fast, convenient online submission

$>$ rigorous peer review by experienced research in your field

$>$ rapid publication on acceptance

$>$ authors retain copyrights

$>$ unique DOI for all articles

$>$ immediate, unrestricted online access

At Auctores, research is always in progress.

Learn more auctoresonline.org/journals/pharmaceutics-andpharmacology-research 